\title{
Simple, scalable and robust purification of two HIV-1 subtype C gp120 monomer subunit antigens for phase II clinical trial in Republic of South Africa
}

\author{
Y Wen ${ }^{*}$, S Stephenson, C Zambonelli, S Hilt, M Wininger, A Dey, S Barnett, A Carfi \\ From AIDS Vaccine 2012 \\ Boston, MA, USA. 9-12 September 2012
}

\section{Background}

Development of an effective vaccine against HIV-1 is challenging due to various viral evolutionary mechanisms to evade human immune system. The partial efficacy of the recent RV144 vaccine efficacy trial in Thailand provides hope for improvements of vaccine regimens for higher efficacy. A Phase IIb proof-of-concept clinical trial in the Republic of South Africa (RSA) is planned to confirm and extend the results of the RV144 trial with the vaccine strategy of poxvirus vector prime plus envelope protein boost.

\section{Methods}

We selected two HIV subtype $C$ gp120 vaccine antigens, TV1.C gp120 and 1086.C gp120, formulated with Novartis proprietary adjuvant, MF59 as protein boosts of the clinical trial.

\section{Results}

To produce TV1.C gp120 and 1086.C gp120 monomers, we generated $\mathrm{CHO}$ stable cell lines for both gp120, which consistently expressed gp120 subunits with high yield. Simple, scalable and robust antigen purification processes were developed to generate both gp120 proteins. The ionexchange based purification strategy enabled the separation of gp120 monomer from dimer and produced gp120 monomer with high purity and homogeneity.

\section{Conclusion}

Purified gp120 monomers were stable, either alone or in combination, and when formulated with adjuvant MF59.

Novartis, Cambridge, MA, USA
Finally, the early evaluations showed that both gp 120 monomers were immunogenic and able to elicit high neutralizing antibody titer.

Published: 13 September 2012

\section{doi:10.1186/1742-4690-9-S2-P356}

Cite this article as: Wen et al: Simple, scalable and robust purification of two HIV-1 subtype C gp120 monomer subunit antigens for phase II clinical trial in Republic of South Africa. Retrovirology 2012 9(Suppl 2): P356.
Submit your next manuscript to BioMed Central and take full advantage of:

- Convenient online submission

- Thorough peer review

- No space constraints or color figure charges

- Immediate publication on acceptance

- Inclusion in PubMed, CAS, Scopus and Google Scholar

- Research which is freely available for redistribution
C Biomed Central

\section{Biomed Central}

@ 2012 Wen et al; licensee BioMed Central Ltd. This is an Open Access article distributed under the terms of the Creative Commons Attribution License (http://creativecommons.org/licenses/by/2.0), which permits unrestricted use, distribution, and reproduction in any medium, provided the original work is properly cited. 